ҚИЯҚТЫ КЕНОРНЫНЫҢ ҚОНЫР КӨМІРІН ТИІМДІ ПАЙДАЛАНУДЫҢ ЖОЛДАРЫ

\author{
Ж.К. Қайырбеков, Е.А. Әубәкіров, *Н.Ж. Жалгасұлы, Ж.Т. Ешова \\ Мақалада Қияқты кенорнының қоңыр көмірінің ұсақ шашыраңқы бөлігін тиімді қолданудың мүмкін \\ болатын жолдары көрсетілген.
}

\title{
WAY OF EFFECTIVE APPLICATION OF BROWN COAL FROM KIAKTY DEPOSIR
}

\author{
Zh.K.Kairbekov , E.A.Aubakirov, N.Zh.Zhalhasuly, Zh.T. Eshova \\ In the present study opportunity of effective application of brown coal small screenings from Kiakty deposit is \\ shown.
}

УДК 665.75:662.8

\section{РАЦИОНАЛЬНОЕ ИСПОЛЬЗОВАНИЕ МИНЕРАЛЬНОГО СЫРЬЯ}

\author{
Ж.К. Каирбеков, Е.А. Аубакиров, *Н.Ж. Жалгасулы \\ НИИ новых химических технологии и материалов \\ *Институт горного дела им. Д.А. Кунаева, Алматы
}

\begin{abstract}
В данной работе проведен систематический анализ проблемы и пути рачионального использования минерального сырья.
\end{abstract}

При взаимодействии человечества с природой все убыстряющими темпами, особенно в последние столетия, происходили: быстрый рост населения, только в последнем столетии население увеличилось с 1,5 до 6 с лишним млрд. человек; увеличение потребности в минеральном сырье (МC) на душу населения; возрастание темпов роста добычи МС в условиях ограниченных, сокращающихся и невоспроизводимых запасов полезных ископаемых (ПИ); увеличение потерь ПИ в процессах добычи, переработки и потребления МС и их отходов; применение не комплексных, с большими отходами, технологически и экологически не замкнутых, открытых и экстенсивных производств в горнодобывающей и перерабатывающей промышленности, и, как следствие, отставание развития комплексной и безотходной переработки МС и их отходов; накопление большого количества не утилизированных отходов - от 90 до 98\% от общего количества добываемого и перерабатываемого $\mathrm{MC}$; увеличение масштабов нарушения и загрязнения ландшафтов; отставание темпов рекультивации техногенных территорий; изменение климата на планете и в отдельных регионах в сторону потепления за счет воздействия на биосферу природных и антропогенных факторов; снижение взаимной адаптации общества и природы путем нарушения саморегуляции и самоочищения природы и недостаточного осознания обществом возможной реализации экологического кризиса с угрозой жизни на планете; снижение ограниченных и невосстановимых запасов ПИ.

В связи с этим возникает глобальная проблема удовлетворения возрастающих потребностей общества в МС путем рационального (разумного) использования запасов ПИ. Под рациональным или разумным использованием запасов ПИ здесь понимается возможно полное и комплексное использование запасов ПИ, путем утилизации всех отходов.

В настоящее время около $70 \%$ промышленной продукции в мире производится из ПИ, извлекаемых из недр. Особенно быстрыми темпами истощаются запасы нефти, газа, угля, алюминиевых руд, цветных и благородных металлов и ядерного сырья (урана-235) /1, 2 /.

Среди отдельных видов ПИ или ископаемых ресурсов на одно из первых мест, по энергообеспечению, энерговооруженности и энергобезопасности следует поставить запасы топлива $13 /$.

Из всех минеральных топлив (каустобиолитов) запасы угля занимают первое место. Общие геологические запасы угля в мире достигают 9-11 трлн. тонн условного топлива, а разведанные запасы составляют 1,2 трлн. тонн, в том числе в Казахстане - 49 млрд. т (седьмое место в мире).

Извлекаемые запасы нефти оцениваются в 250- 375 млрд. тонн условного топлива (не считая горючих сланцев и битуминозных пород). Запасы природного газа по некоторым данным соответствуют 27 млрд. тонн условного топлива /3, 4/. 
Таким образом, разведанных запасов угля больше запасов нефти в 3 раза, газа - в 4,3 раза, прогнозируемых запасов угля больше запасов нефти и газа в десятки раз $/ 4,5 /$.

Как известно, минеральные ресурсы относятся к невозобновляемым (кроме соли и торфа) и их общие запасы быстро уменьшаются в условиях удвоения добычи и переработки через каждые 8-18 лет по отдельным видам ПИ. Поэтому богатые месторождения с высоким содержанием полезных компонентов (ПК) уже отработаны и в настоящее время разрабатываются в основном только бедные месторождения ПИ. Так, содержание меди в рудах разрабатываемых месторождений снизилось с $10 \%$ в начале XIX века до 1\% в наши дни.

Такое же положение с запасами и в Республике Казахстан. С учетом запасов месторождений Жаман-Айбат, Тоскура и Жартас, меди хватит на 35 лет /6/.

Катастрофическому истощению запасов ПИ способствуют такие факторы, как:

- снижение темпов геолого-разведочных работ по расширению запасов на известных месторождениях и поиск новых месторождений ПИ;

-отсутствие мобильных эксплуатационных кондиций;

- потери МС при добыче, транспортировке, хранении, переработке и использовании готовой продукции и полуфабрикатов;

-низкое извлечение полезных компонентов (ПК) из МС;

- недостаточное внимание к ресурсосбережению, к экономии сырья и материалов;

- недостаточное использование вторичного сырья;

- слабая утилизация твердых, жидких, газообразных и тепловых отходов в виде породных шлаковых, золовых отвалов, хвостохрани-лищ, выбросов в атмосферу, сточных вод и тепла отходящих газов;

- недостаточное внимание к разработке и применению малоотходных и безотходных технологий;

-слабая заинтересованность в охране недр и окружающей среды;

недостаточное внимание к разработке и применению альтернативных источников $\mathrm{MC}$ и заменителей ПК и продукции из этого МС.

Bce это вместе взятое снижает эффективность производства в горнодобывающей промышленности и в смежных отраслях и создает экологическую напряженность.

Повышения эффективности или рационального использования МС включает совершенствование способов разведки и подсчета запасов ПИ, изучение вещественного состава ПИ и вмещающих пород, геолого-технологическое картирование, разработку научно-обоснованных методов прогноза инженерно-геологических и гидрогеологических условий эксплуатации месторождений/7/. Необходимо широкое применение и совершенствование геофизических способов и методов разведки, дистанционных способов исследования земной коры с самолетов и спутниковых систем, применение новых экспрессных методов анализа, основанных на применении физических и ядерно-физических процессов.

Необходимо, чтобы геологические организации оценивали месторождение не только по основным компонентам, но и учитывали экономический и экологический эффект от попутной добычи других ПИ и утилизации отвальных пород. Так, по большинству ранее разведанных медных месторождений Урала и Казахстана не определены запасы содержащихся в них никеля, висмута, селена, теллура, серы, и других ПК/7/.

Для более обоснованного выбора систем вскрытия, подготовки и разработки месторождений ПИ, схем обогащения для имеющихся типов руд и гарантии более полного использования МС необходимо повышение полноты и качества информации о месторождениях ПИ путем геологотехнологического картирования всех рудных тел и содержащихся в них элементов. Так из несколько десятков элементов, содержащихся в рудах Жезказганского месторождения, в настоящее время извлекается лишь несколько ПК. По состоянию на 01.01.2000 г. из балансовых запасов Желандинской группы месторождений добывалось 719024 тыс. т руды. Из этой руды извлекалось только 7610,6 тыс. т меди, 727,8 тыс. т свинца, 811,0 тыс. т цинка, 9227,0 кг серебра и 799,1 кг рения. Остальные химические элементы не извлекались.

В условиях постоянного и непропорционального изменения уровня цен и затрат необходим переход от постоянных кондиций на ПИ, залегающие в недрах, и МС, выданное для переработки, к переменным, что позволит поддерживать определенный уровень рентабельности производства, более эффективно использовать ограниченные финансовые ресурсы и расширить сырьевую базу месторождений ПИ. 
Переход с постоянных на переменные кондиционные требования к руде и ПК извлекаемые из МC должен также учитывать изменение затрат на извлечение ПК из МС при комплексной (малоотходной и безотходной) переработке МС и отходов его добычи и переработки.

Этот переход с постоянных на мобильные кондиции должен быть осуществлен на базе вновь созданных научных основ экономической оценки месторождений ПИ, учитывающих новые условия рыночной экономики.

В условиях рыночной экономики разработанные ранее методики экономической оценки месторождений ПИ не позволяют рационально и комплексно, разрабатывать минеральные запасы недр и перерабатывать МС и их отходы, так как эти методики основаны на постоянных затратах, оптовых ценах и нормативных коэффициентах эффективности капиталовложений, по которым учитывается фактор времени при дисконтировании затрат. Кроме того, в условиях рыночной экономики государство не вмешивается в установленные сроки окупаемости инвестиций частных и государственных предприятий, а, следовательно, и не устанавливает нормативных коэффициентов эффективности вкладываемых в производство инвестиций.

Горно-техническое направление рационального использования минеральных ресурсов включает совершенствование применяемых и создание новых технологий, добычи и переработки МС, которые повышают полноту, комплексность и качество извлечения ПК из недр и из отходов МС.

Технику и технологию возможно классифицировать по способам и процессам разработки. По первому признаку, как известно, техника и технология создается для открытых, подземных ,геотехнологических и комбинированных работ. По второму признаку техника и технология разделяется по назначению для вскрытия, подготовки месторождений к отработке и для отработки месторождений ПИ. Следует добавить к этим видам технологий также технику и технологию для комплексного извлечения ПК из руд, для переработки вторичного сырья и отходов добычи и переработки $\mathrm{MC}$, для восстановления ландшафта на техногенных территориях путем рекультивации нарушенных и засоренных земель.

Для каждого типа месторождений и ландшафтов для всех этих процессов жизненного цикла отрабатываемых месторождений ПИ при научно-технической подготовке горного производства, (включающей фундаментальные и поисковые исследования, разработку техники и технологий, проектирование и конструирование, создание техники и технологий, испытание и доводку, строительство объектов горнодобывающего и перерабатывающего производства) должна создаваться техника и технология, в наибольшей степени адаптивной к изменяющейся природной и социальной среде, подсистемами элементов максимально соответствующими друг к другу по критериям рационального и комплексного использования минеральных ресурсов, путем малоотходного и безотходного производства.

При таком системном подходе, с точки зрения рационального, в том числе комплексноэкономического направления отработки недр, необходимо пересмотреть направления развития горного и перерабатывающего производства для совершенствования существующих технологических процессов добычи и переработке МС и их отходов, которые позволят наиболее эффективно извлекать все содержащиеся в нем ПК, вовлечь в переработку бедные и забалансовые руды, в основном нетрадиционными способами.

Таким образом, в результате рационального использования МС путем его комплексной и безотходной переработки, отпадает необходимость решать социальные проблемы по переселению населения в новые районы добычи МС, их переобучения и переквалификации.

\section{Литература}

1. Новиков Ю.В. Охрана окружающей среды. - М.: Высшая школа, 1987. - С. 287.

2. Банников А.Г. и др. Охрана природы. - М.: Агропромиздат, 1985. - С. 287.

3. Экономика природопользования. - М.: Изд-во МГУ, 1991. - С. 271.

4. Шицкова А.П., Новиков Ю.В. Гармония или трагедия? Научно-технический прогресс, природа и человек. -

М.: Наука, 1989. - С.270.

5. Михеев А В. Константинов В.М. Охрана природы. - М.: Высшая школад986. -С. 256.

6. Сырьевая база свинца и цинка, меди, золота Казахстана. - Алматы: Казахстанское геологическое общество «КазГео», 2002. - С. 104.

7. Певзнер М.Е., Костровецкий В.П. Экология горного производства. - М.: «Недра», 1990. 


\section{МИНЕРАЛДЫҚ ШИКІЗАТТЫ РАЦИОНАЛДЫ ҚОЛДАНУ}

Ж.К. Қайырбеков, Е.А. Әубәкіров, *Н.Ж. Жалгасұлы

Бұл жұмыста минералдық шикізаттарды үнемді пайдаланудың жолдары мен мәселелеріне жүйелі талдау берілген.

\section{MINERAL RAW MATERIALS CONSERVATION}

Zh.K. Kairbekov, E.A. Aubakirov, N.Zh. Zhalhasuly

In the present study systematic analysis of problem and ways of mineral raw materials conservation are performed.

\section{УДК 547.992.2}

\section{ХИМИЧЕСКИЕ СВОЙСТВА ГУМИНОВЫХ КИСЛОТ}

\section{Ж.К. Каирбеков, Э.Т. Ермолдина, Н. Ережеп, Р.Д. Шингисова, Ж.К. Мылтыкбаева \\ Казахский национальный университет имени аль-Фараби Факультет химии и химической технологии}

В данной работе были проведены физико-химические анализы гуминовых кислот. Было установлено, что гуминовые кислоты - природный полимер можно использовать в качестве модификатора катализаторов .

\section{Введение}

Угли являются ценнейшим углеродистым сырьем для получения разнообразных химических продуктов. Наиболее важными продуктами из них являются гуминовые кислоты, прикладная значимость которых, с каждым годом возрастает [1].

Согласно литературным данным [1, 2, 3], гуминовые кислоты представляют собой неоднородную смесь природных высокомолекулярных азотсодержащих органических кислот, молекулы которых содержат ароматические группировки. Гуминовые кислоты - поликомпанентные соединения, неоднородные по своему составу. Их состав и поликомпанентность зависит от природы источников образования, механизмом биохимических реакций, сопровождающих процесс формирования и условиями их геохимической трансформации.

Несмотря на то, что состав гуминовых кислот хорошо изучен, до сих пор не найдена химическая формула, так как их состав многообразен и зависит от многих факторов.

Гуминовые кислоты способны к различным химическим превращениям и представляют богатейший исходный материал для получения многообразных по назначению материалов.

В данной работе исследованы физико-химические характеристики ГК из угля месторождений «Куньмин», «Ой-Карагай» и «Мамыт».

\section{Методы и материалы}

Для получения гуминовых кислот применяют метод экстрагирования щелочью из исходного угля. Для повышения выхода гуминовых кислот из углей Мамытского и Куньминского месторождений был использован метод окисления их 8 M НNO . Выделение гуминовых кислот из окисленных углей проводились при определенных оптимальных условиях.

\section{Результаты исследования}

Были определены влажность и зольность неокисленного и окисленных углей, которые представлены в таблице 1.

Таблица 1 - физико-химические характеристики угля Мамытского и Куньминского месторождений

\begin{tabular}{|l|l|l|l|l|}
\hline Месторождение & Навеска угля, $\Gamma$ & $\begin{array}{l}\text { Влажость масс. } \\
\%\left(\mathrm{H}_{2} \mathrm{O}\right)\end{array}$ & Навеска угля, $г$ & $\begin{array}{l}\text { Зольность, масс. } \\
\%\end{array}$ \\
\hline Куньминское & 1.0 & 7.4 & 1.0 & 4.2 \\
\hline
\end{tabular}

